long range seismic recording alone. The present detection threshold is about magnitude four, and 80-85 per cent of the earthquakes above this magnitude are identifiable. A recent Swedish memorandum to the committee has suggested that by processing the data in a certain way, and by the use of decision theory, the data now available are sufficient to provide at least a degree of deterrence to countries contemplating underground nuclear explosions. It is clear, though, that it is still not possible to distinguish with absolute certainty between explosions and earthquakes without on-site inspections. As Mr Mulley put it, "It may be that with further technological progress scientific techniques alone may provide the answer, even without on-site inspections . . but my government does not believe that this point has yet been reached". Meanwhile the test ban treaty shares with the non-dissemination treaty the problem of inspection-and, of course, the depressing thought that neither France nor China has any intention of signing it.

\section{Ten Years Old}

IT is difficult to look back with much enthusiasm on the ten years in which the International Atomic Energy Agency has been in existence. The acquisition of nuclear weapons by China and France, and the adoption of idiosyncratic foreign policies by these two states, represents just the kind of situation that the IAEA was set up to prevent. Indeed, so limited were the powers accorded to the new organization at its inception that its failure was predictable even then. The agency may inspect nuclear installations only at the invitation of governments, and its fiercest sanction is to report misdemeanours to the General Assembly of the United Nations. At present, more than sixty plants in twenty-six countries are under its observation, but none of these is in France, West Germany, the Soviet Union, or, of course, China. Of the technologically advanced countries, only Japan, inspired by memories as well as reason, has co-operated whole-heartedly with the IAEA. Until more of its member states follow this example, the agency can only continue to gain experience of inspecting installations. This month one of its teams is investigating a newly built fuel reprocessing plant for the Yankee reactor at West Valley, New York. This is the first time that a plant other than a reactor has been inspected.

The IAEA has been more successful where its activities have not impinged on politics. More than two thousand five hundred fellowships have been awarded, and a large number of training courses arranged. Research is being undertaken into desalination, pest control by irradiation, the use of isotopes in medicine and hydrology, and other projects. Yet the budget of the agency is minute compared with that of national atomic energy authorities. In 1967, of a total of twelve million dollars, only three-quarters of a million were spent on research projects. The amount will rise by a mere fifty thousand dollars next year, according to the recently published budget for 1968 . Even among the United Nations agencies, the IAEA is something of a Cinderella; WHO operates on a budget of nearly sixty million dollars.

Had the research work of the agency been more extensive, its control over the activity of member states might have been greater, for its statutes stipulate that all of the agency's aid projects shall be open to inspection. As it is, with the bulk of nuclear research being done in regions far from Vienna, international projects have been set up independently of the IAEA, and only occasionally has the agency been invited to join the agreement, as a superfluous matchmaker. With the authority of scientific achievement, the IAEA might speak with a different voice, and be heard.

\section{Organizing Steel}

DETATLS of the organization of the British Stecl Corporation were recently completed, and have been published as a White Paper (HMSO, 4s.). The corporation came into existence on July 28 , when fourteen British steel companies were nationalized. The BSC will have a total turnover of more than $£ 1,000$ million, and will employ 270,000 people; this, the White Paper notes, will put it among the six largest undertakings in the free world-outside the United States.

The organization takes into account two opposing forces, geography and product. Geographical groupings help in the physical problems of management and communications, but destroy valuable product links between companies. Grouping on product lines makes management, sales and research easier to co-ordinate, but reduces freedom of choice for the consumer and makes competition between the groups harder to sustain. In the event a compromise between these forces has been struck, and four regional groups are named in the White Paper. The Midland Group, centred in Sheffield, will do much of the stainless and special steel production; the Northern Group will look after tube, the Scottish and Northern Group strip milling and coated sheets. and the South Wales Group will account for the whole UK production of transformer sheet and tinplate. It is clear, though, that the groups will not be limited to these products, and a generous amount of overlapping on the more common steel products is likely.

The report says little about research and development in the corporation. Dr H. M. Finniston, as deputy chairman-technical, will have two directors reporting to him, one on engineering, and the other on research and development. The director of engineering will look after the exploitation of research and development work, advise the groups on the engineering aspects of major capital projects, and distribute technical information. The director for research and development will be concerned with all the central research activities, technical processes, product development and measures designed to improve working conditions. The White Paper makes a point of mentioning that he will use techniques such as operational research. The names of the directors have not yet been announced.

The philosophy of the White Paper seems to be to develop a less monolithic structure than is customary in British nationalized industries. "Within the concept of a single, unified corporation, we consider that the Groups should have the greatest degree of operating autonomy and profit accountability. The spur of competition, other than in price, between the groups and the units below them is in our view highly desirable." Price competition, though, says the White Paper, is both unattainable and undesirable within a 